\title{
Active Learning: Faculty Mind-sets and the Need for Faculty Development
}

\section{Dr. Angélica Burbano, Universidad Icesi}

Angelica Burbano C. Associate Professor Universidad Icesi at Cali, Colombia. Ph.D. in Industrial Engineering from the University of Arkansas. MSOM from Universidad Icesi and BS in industrial engineering from Pontificia Universidad Javeriana both in Cali, Colombia. Fulbright Scholar 2007 and a fellow AOTS, Japan 2000. She has previous experience (six years) in the food manufacturing industry (experience related to inventory management and production planning and control, also information systems such as ERP). During her studies in the United States she worked a research assistant at the Center for Innovation on Healthcare Logistics CIHL, her work for CIHL focused on assessing the impact of GS1 standards adoption in the healthcare supply chain. Her research interests are related to the adaptation of existing manufacturing and logistics models and structures to the healthcare supply chain with a specific focus on medical supplies. She is also interested on engineering education research. She is part of the IE Department at Universidad Icesi since 1998. She has over fifteen years of teaching experience and served as Director of the Undergraduate Program in Industrial Engineering (2003-2007), Director of the graduate program in Industrial Engineering ( August 2012 - August 2014), and she is currently the IE Department Head.

\section{Ms. Katherine Ortegon, universidad icesi}

Ing. Katherine Ortegon Mosquera., Assistant Professor, Universidad Icesi.

Education: Ph.D., Ecological Sciences and Engineering (ESE-IGP) \& M.S., Ecological Sciences and Engineering, College of Engineering, Purdue University, West Lafayette, IN. Specialist in Environmental Management. Universidad Icesi, B.S., Industrial Engineering. Fulbright Scholarship, Sponsor: FulbrightColciencias 2009-2012

Teaching experience: Assistant Professor, Universidad Iceesi, lectures include: Life Cycle Engineering, Renewable Energies, Methods in Engineering (manufacturing and service industry) \& Process Improvement.

\section{Ms. Silvia Guzman}

I am currently a research assistant with the Engineering Dep., Universidad ICESI, Cali - Colombia. It also develops consulting projects to business growth and science, technology and innovation. Prior to this I was a project management and estructuring executive of Innovation and Business Development area, Innpulsa - Colombia, Colombian Ministry of Industry, Trade and Tourism; Projects Coordinator Strengthening of Higher Education, Universidad UNAB, Mutis University Network and Colombian Ministry of National Education. My professional experience related to education projects management (quality and pertinence), business quality, supply chains, innovation and engineering education. I am an Industrial Engineer from the Universidad Industrial de Santandar - UIS, Colombia; and Master Engineering - Universidad ICESI.

\section{Prof. Henry Arley Taquez Quenguan, Universidad Icesi}




\title{
Active Learning: Faculty mindsets and the need for faculty development
}

\begin{abstract}
This research paper explores the characterization of Active Learning (AL) practices in the School of Engineering at Universidad Icesi. A survey designed to identify faculty understanding of AL and to characterize classroom practices was developed during summer 2017 and subsequently administered to 144 faculty members. Sixty-five (65) written definitions of AL were gathered, coded, and analyzed. One hundred-thirty-six (136) activities detailed in the survey were analyzed according to an inventory of twenty-two (22) AL activities developed at Northwestern University. Findings suggest, first, that there is no consensus on a definition for AL; second, that the activity "reading before class" is typically misunderstood as an AL activity; and third, that there cannot be an implementation of AL by faculty members without providing them the proper training and competencies required to design learning strategies oriented toward AL.

The contribution of this paper is twofold. First, the current study will raise awareness among faculty members at the School of Engineering at Universidad Icesi that they must reflect not only on the instructional design of their courses but also on opportunities for self-improvement. Second, it will aid department heads in identifying areas in which to focus faculty development efforts. At Universidad Icesi, these results have led to changes in the School of Engineering at both the school and departmental levels. Finally, a proposal for a preliminary plan for faculty development is presented. Presentation method: traditional lecture.
\end{abstract}

\section{BACKGROUND AND SUPPORTING LITERATURE Concepts about active learning}

There exists extensive literature dedicated to the concept of active learning (AL). Some authors have described AL based on its characteristics [1] while others have made more specific definitions, describing it alternately as a strategy, a technique, an instructional method or a model [2], [3]. Defining AL based on its characteristics implies that students must engage in activities beyond the basic ones such as listening, paying attention, or taking notes. Students must be able to read, to question themselves, to write, to discuss, to apply concepts, to employ methods, to solve problems or challenges or develop projects in a real-world context [1].

A common aspect found throughout these different approaches is the student's motivation and engagement with her or his own learning process. However, achieving this engagement is not an easy task for faculty members due to resistance from students to these new approaches. According to the literature, student opposition is a natural phase when moving from passive learning tied to the professor towards a learning based on intellectual autonomy[1], [4], [5]. 


\section{Key elements and benefits of $A L$}

According to Gonzalez [1], instructional design using AL includes at least three elements, achieving student engagement, considering and understanding learning styles, and promoting a classroom environment where students reach high-order thinking through questions posed by the professor. In this regard, there is no evidence that matching instructional design activities to one's learning style improves learning, however, it is important that each student reflect and recognize their own learning styles. Daouk, Bahous and Nola [6] suggest that AL basic elements include speaking, reading, listening, writing, and reflecting. Thus, students must become more proficient in communicating (i.e., orally and written) as well as becoming more critical readers and listeners. Other elements of AL include the significant learning gained from and with others. The constructivism theory suggests a variety of techniques to promote AL based on the principle that students build their own knowledge through exposure to learning environments that invite them to engage in a more active learning process.

Among the benefits of AL are the development of high-order thinking skills such as analysis, synthesis, evaluation, and creativity. It also promotes the development of critical thinking and strengthens the interaction between professor and student, and among students. Additionally, AL allows for the development of activities where the student has the opportunity to connect her or his learning process with real-world contexts. Furthermore, students develop autonomy, reflect, and are aware of their own learning gaps, which then triggers their learning [6], [7]. There is a broad list of instructional techniques that promote AL in students. Typically, these techniques are classified from low to high complexity according to the effort required by the professor and the students. Low complexity techniques include visual aids, one-minute papers, affective responses, and flipped classroom. High complexity techniques include problem-based, challenge-based, or project organized learning [6],[9].

\section{Faculty Development}

Faculty development (FD) is defined as a group of activities designed to improve faculty members' performance in teaching practice, research or management. FD also allows faculty members to adapt themselves to a changing environment in a creative and innovative way [10], [11]. A variety of studies have been developed looking for assessing FD methods, forms of implementation, impact, barriers and challenges [12],[16]. FD programs have been classified in different ways. For instance, oriented toward the development of workshops, the construction of learning communities, and the development of competencies. However, there is a growing interest in providing FD programs that truly have an impact on teaching practice. In this sense, it is important to move forward and assess the impact of FD on daily practice (i.e., reflection, teaching practice, and student learning). An important aspect that is gaining relevance is the possibility of seeing the professor as a student that is learning-to-learn with others; this is important when facing the typical challenges that arise within teaching practice. This requires a professor with the ability to reflect, to take action in the classroom, and most importantly, to find creative alternative solutions in order to improve continuously. Furthermore, FD brings the opportunity to develop research in the classroom. This invites the professor to assume her or classroom as a lab where it is possible to experiment, practice, assess, evaluate and reflect. 


\section{METHODOLOGY}

A descriptive case study was developed in the School of Engineering at Universidad Icesi. The School of Engineering includes the Departments of Industrial Engineering, Software and Telecommunications Engineering, Biochemical Engineering, Industrial Design, and Physical Sciences.

A survey containing two sections with a total of fifteen (15) questions was designed to explore faculty perceptions and practices in Active Learning (AL) (Appendix A-Survey). The first section of the survey, consisting of eight closed-answer questions, served to characterize the population in terms of training received and average class size. The second section, comprised of seven openanswer questions, was designed to characterize knowledge about AL and current practices used in the classroom. Faculty members were asked for their definition of the concept of AL and to describe three activities developed in their classes, as well as information regarding preparation time, difficulties during implementation, impact on content and evaluation, and development of competencies. The survey was applied through the department heads to 144 faculty members during the first semester of 2017. Answers from $45 \%$ of the population (i.e., 65 responses) constitute the sample of this study. According to the statistical analysis, with a level of confidence of $95 \%$ and a $10 \%$ margin of error, a sample size of 58 responses was required to achieve accurate inferences.

\section{Information processing and analysis}

A reliability analysis was developed to ensure that the instrument used (i.e., the survey) provided accurate results. Cronbach's alpha $(\alpha)$ coefficient was used for this purpose. The alpha coefficient was 0.70 , indicating high consistency among responses analyzed.

Responses gathered from the second section of the survey were individually analyzed and classified by 4 experts. An inventory of AL activities developed by Van Amburgh, et. al. [17] was the framework used to classify the AL activities described by faculty members. Each expert classified the activities mentioned by faculty members using the inventory of 22 AL techniques suggested in the framework. These techniques are classified by level of complexity from A to V, with A being the least complex, according to the effort and time required for design and implementation. Later, a second revision was undertaken in order to analyze the activities where discrepancies were in evidence with the goal of reaching a consensus among the evaluators. The Kappa Fleiss (0.7) statistic was used to measure the reliability agreement among experts. In other words, there is a high probability of agreement among the 4 experts when classifying the AL activities in light of the inventory suggested by Northwestern University.

\section{RESULTS AND DISCUSSION}

The results of sections I and II of the survey are presented here along with the proposed faculty development plan. 


\section{Survey Section I}

The first section of the survey provides information to explain the context and characteristics of the population of this study. This characterization of the population was used to understand the context and possible relationships between AL activities used by faculty and aspects such as training received, class size, among others.

The School of Engineering is the second oldest school at Universidad Icesi, a 40-year-old institution. It's Institutional Educational Project (PEI, for its acronym in Spanish), which explicitly describes AL as a foundation for its academic programs, characterizes Universidad Icesi. Class size at Universidad Icesi is approximately 20 students; small classrooms are a characteristic of our institution. In the survey, $18 \%$ of the faculty members indicated having 15 or fewer students, $35 \%$ indicated having a classroom size between 16 to 20 students, $22 \%$ between 21 to 25 students, $15 \%$ between 26 to 30 students, and $10 \%$ above 31 students. In relation to the question about participation in training programs in teaching, the answers indicate that $74 \%$ of the respondents have received some training while the remaining $26 \%$ have not.

\section{Survey Section II}

\section{Faculty mindsets about active learning}

As part of the survey, faculty members were asked to describe their understanding of AL in nontechnical language. The goal of this question was to identify faculty mindsets, assess the clarity of the concept, and understand the relationship between what professors think AL is and what they actually do in class. Moreover, the survey scrutinized aspects related to AL environments, such as faculty members' perceptions about the development of competencies, content development, and time consumed for class preparation.

The literature on the AL concept suggests a variety of approaches [1], [4], [18], [19]; the concepts suggested by the faculty surveyed were no exception. Sixty three percent $(63 \%)$ of responses were classified according to the categories (keywords) explicitly recognized in the faculty members' answers (Fig 1). For example, "AL is an interactive process between the professor and the students to teach/learn" The remaining 37\% were not classified due to a lack of clarity or uncertainty in their definition. According to these results, there is no clear consensus about what AL actually is; responses among faculty members are as diverse as those presented in the literature. 


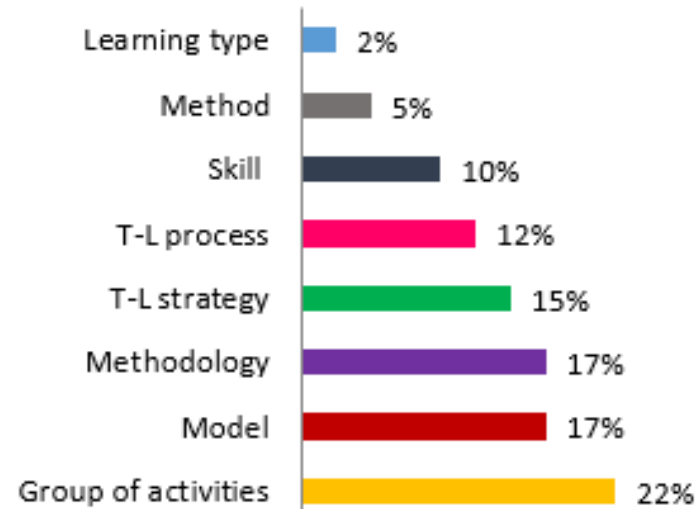

Fig 1. Classification of faculty definitions of AL based on the keyword used

A deeper analysis allowed for the classification of faculty members' responses into three groups according to the characteristics described (Fig 2). In the first group, the AL concept is based on the student. These definitions recognized an autonomous and engaged student who is conscious of her or his learning process. The student participates, interacts, develops her or his own skills, and construct her or his own knowledge. The second group includes definitions recognizing the relationship between the professor and the student. This group described the roles of each and their joint responsibility in the construction of knowledge. This group also recognized the importance of the classroom environment and learning strategies used to achieve the learning goals. In the third group, the AL concept is based on the activities developed. Thus, AL is described as a group of activities developed before, during, or after class, virtually or face-to-face. These activities are designed by the professor in order to motivate, engage, and facilitate the teaching-learning process. According to these results, professors' first mindsets are that AL is a practice based primarily on students. This implies that they did not recognize themselves as active actors of the learning process. Consequently, there are improper course instructional designs; students complain about the lack of guidance; and engagement and motivation are reduced, which results in the competencies not being attained or the learning goals not being achieved.

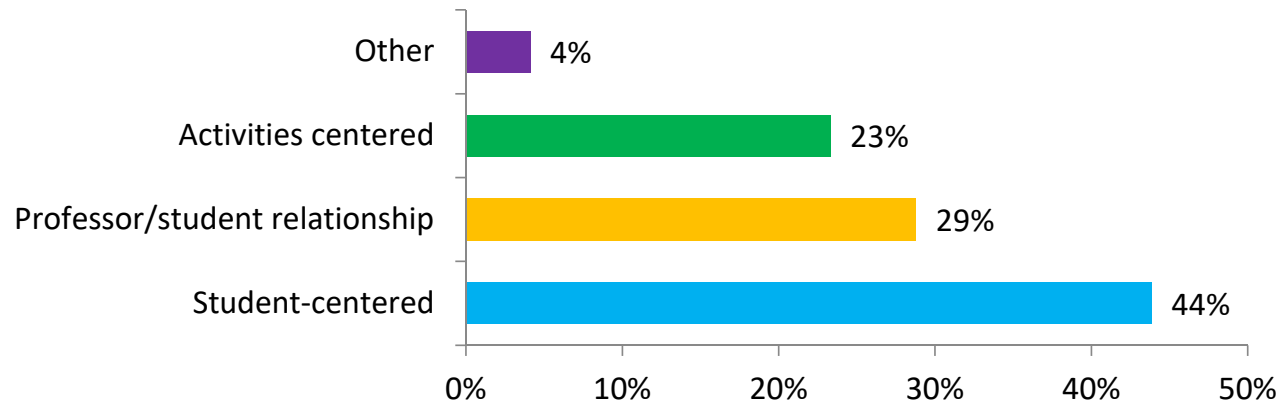

Fig 2. Classification of faculty definitions of AL based on the characteristics' classification 
When exploring aspects related to the AL environment, it was discovered that $68 \%$ of faculty members considers that there is a high relationship between the implementation of AL activities and the development of student competencies. Likewise, $57 \%$ consider that class preparation time is higher than traditional lectures; $57 \%$ express never or almost never having had difficulties while implementing AL in their classes. In reference to content coverage, there is no consensus among the professors. It is important to highlight that this section of the survey was exploratory, and not all the faculty members surveyed responded to these questions.

Similar results related to the impact of AL in the development of competencies and the preparation time are found in the literature [17]. However, difficulties encountered during the implementation and the impact on content coverage varies, which could be the result of a lack of faculty members' reflection on their teaching practice or knowledge about what AL truly means.

\section{Characterization of Active Learning practices}

As part of the survey, faculty members were asked to mention up to three activities they typically implement in class. A total of 186 activities were gathered, $73 \%$ of the responses (i.e., 136 activities) were classified in terms of the inventory of 22 AL activities presented by Van Amburgh, et. al. [17]. According to results presented in Fig 3, activity G (i.e., application activity) is the most frequent $(25 \%)$ practice among faculty members. Application activities include, for instance, solving real-world problems in class, field trips to companies, or lab activities. This is followed by activity $\mathrm{V}$ (i.e., cooperative learning/problem-based learning) with $15 \%$ and activity $\mathrm{M}$ (i.e., roleplaying, simulations and games) with $13 \%$ frequency. Cooperative learning is typically associated to final course projects and simulations are associated to ludic games or software simulations used in class These results are not surprising due to the fact that engineers are typically oriented toward problem-solving in real-world contexts. Although the inventory of AL techniques provides a framework for characterization, it is limited when assessing the evolution or improvement of teaching practices. In other words, it does not explain why faculty members combine activities of low-medium complexity with activities of high complexity or how well these activities are implemented. 


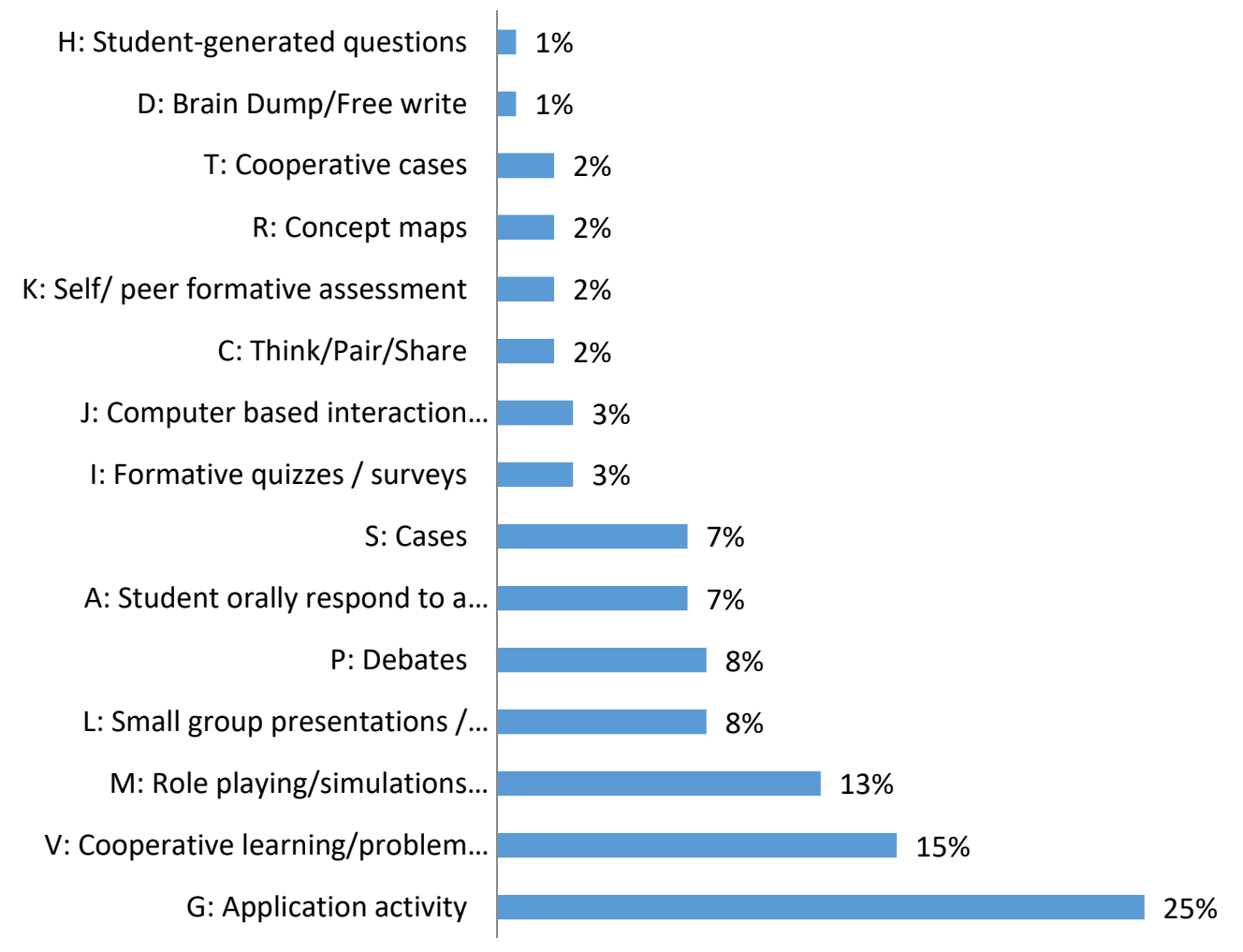

Fig 3 Classification of activities used by faculty members according to the AL inventory

The remaining $27 \%$ of the responses (out of 186 activities described) did not fit the inventory descriptions yet were also analyzed in order to understand faculty members' perspectives (Fig 4). This unexpectedly revealed the second mindset about AL. Fifty percent (50\%) of responses indicated that professors believe that "reading before class" is an AL practice. This is concerning since having an assigned reading does not guarantee the student will acquire the competencies expected or achieve the learning goals. The reading is a resource for learning and must be accompanied by a reading guide, a class discussion, and reflection on the topic discussed. Similarly, professors consider audiovisual aids (12\%), reading guides (10\%), and project followup (8\%) as part of their AL practices, but those are learning resources. A small percentage of them mentioned research practice and lab classes as examples of their AL activities. Based on this, it appears that faculty members misunderstand the difference between learning strategies, learning resources, and learning activities. As a consequence, courses designed based on the use of learning resources (e.g., labs) are content-oriented instead of competencies-oriented. 


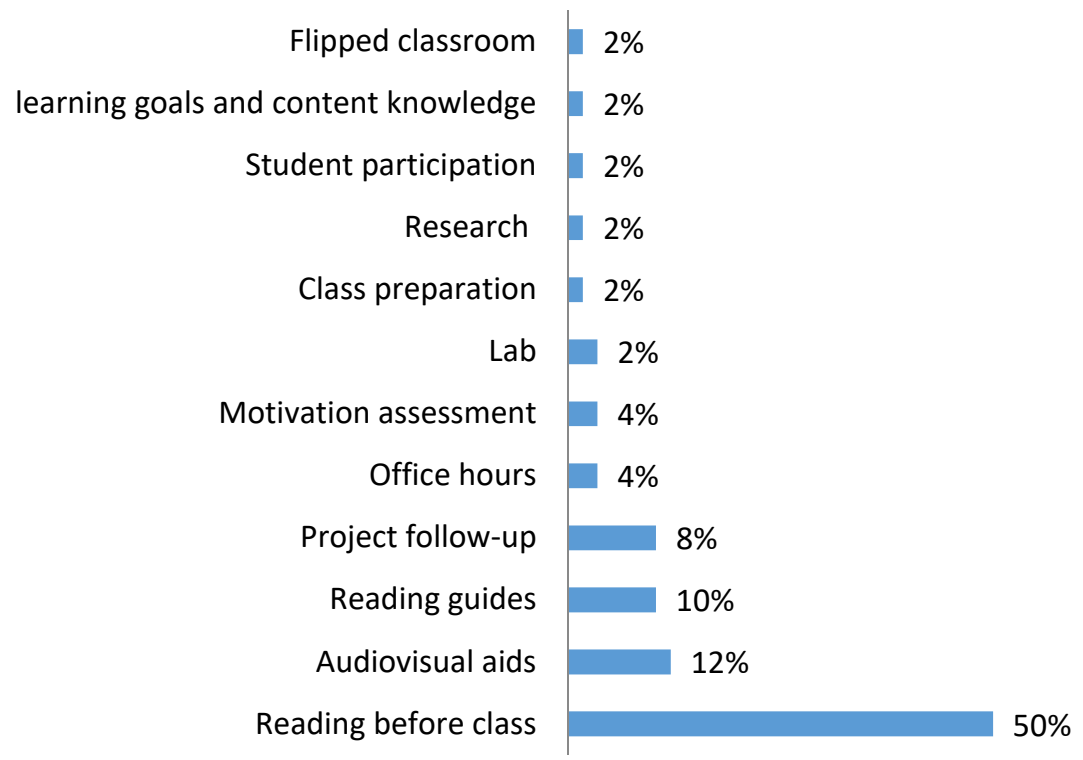

Fig 4 Classification of activities used by faculty members that did not fit the AL inventory

As mentioned previously, some aspects of the population's characterization can be associated with AL. In the case of training received, there is a correlation between professors who have received pedagogical training and the use of AL in class. Faculty members who have received pedagogical training (i.e. $74 \%$ out of 65 respondents) exhibit a higher frequency in implementing activities $\mathrm{G}$ (application-26\%), M (role-playing-12\%) and V (PBL-16\%) in their classes, and all faculty members who have not received pedagogical training do not report using activities D (brain dump/free write), K (self/peer formative assessment), and R (cases studies).

Lastly, relationship between class size and the difficulty of implementing AL activities was analyzed. Findings suggest that there is no consensus on the issue. Fifteen percent $(15 \%)$ of professors declared never having had difficulties with a class size of 16 to 20 students; $20 \%$ of professors declared almost never having had difficulties with a class size of 20 to 25 students. However, when asking about a class size of 31 to 35 students, professors declared that they almost always had difficulties. This could be due to the Universidad Icesi small class size policy (20 students per class on average). 


\section{Faculty development Plan}

By the end of 2017, survey results were presented to the Center for Teaching and Learning (CREA, for its acronym in Spanish) and to all faculty members in the School of Engineering. The CREA is a centralized unit in charge of providing training in instructional development to faculty members across the campus. Three main findings emerged from this presentation. First, this was the first time in the 20 years since the introduction of the PEI (Institutional Educational Project) that faculty members were revisiting what AL means. The fact that "reading before class" was a main finding in the survey drew their attention. Second, faculty members recognized the need for faculty training and support not only from the CREA but also from the School of Engineering. Even though there is a centralized general offering, they would like to have more specialized knowledge in terms of examples of activities applied and implemented in engineering. Third, faculty members recognized the need not only for self-reflection but also for collectively sharing classroom experiences [20].

A plan for faculty development focused on instructional development to fulfill the identified need is proposed in Appendix B. This plan could also take into account other faculty aspects (e.g., research, administrative training). In the proposed plan, a given program is characterized by faculty career stage and considers six elements (participation, complexity level, funding, program type and evaluation). This elements are explained in the following paragraphs.

Participation of faculty members in training programs could be mandatory or not according to individual departmental hiring and promotion policies. To date, no policies are in place; every department has its own policies. Regarding incentives, it is known that faculty members' participation might increase with the providing of incentives. Complexity level is defined as the background required to implement the information or training received. Funding would depend upon the entity offering the program; funds could be institutional (the Center for Teaching and Learning) or could come from a given school. The various programs can potentially be developed as workshops, certificate programs, faculty reflection or discussion, and the focus can be on either theoretical foundations or practical applications. For example, during 2018, various programs related to collective reflection by academic departments were developed [21]. Programs such as Lunch and Learn were created for collective reflections in June and December. A given program can be evaluated solely through attendance or with a satisfaction survey, however this indicator (i.e., satisfaction survey) is not sufficient. The impact of a program must be evaluated based on faculty member teaching practices and, more importantly, on student learning performance.

In this research, no impact is being measured yet, however the preliminary results have shown that with the current faculty evaluation system in which each faculty member must reflect individually and collectively, faculty members can identify training gaps. In 2019, the evaluation will be supplemented with classroom observation, in particular to look for the impact of training on teaching practices or changes in the way faculty members teach. 
The proposed plan will be accessible to all faculty members in order to review and select, based upon their needs, what training they would like to receive. The programs being offered will be coordinated at the school and institutional levels. Enrollment will be agreed upon the faculty member and her department head based on the work plan. The proposed structure was validated with the department heads in the School of Engineering in a series of meetings held in summer 2018.

Faculty members can be grouped or classified by career stage bearing in mind that needs for faculty training would be different according to the stage [10]. During 2018, a series of programs were proposed and funded by the School of Engineering (Table 1). There was also an institutional offering of faculty development programs that is not presented here but is available on the CREA website (https://www.icesi.edu.co/crea/talleres_de_formacion_docente_2014.php). The first and last programs in Table 1 were meaningful. After the first program on $\overline{A L}$, faculty members were asked about what they would like to learn about, and the subsequent search for funding and experts were undertaken taking this direction into account. The last program offered on research on engineering education allowed faculty to link their research work and findings in the classroom with research on engineering education.

Table 1. Faculty development programs offered by the School of Engineering during 2018

\begin{tabular}{lll}
\hline Expert & Program & Date ( 2018) \\
\hline Michael Prince & Active Learning workshop & January 11 and 12 \\
Anastassis Kozanitis & Rubrics and Evaluation & June 26 and 27 \\
Eulises Domínguez & Classroom assessment techniques & July 26 and 27 \\
Erik de Graff & Facilitation and PBL & September 10 and 11 \\
Camilo Vieira & Engineering education research & December 11 and 12 \\
\hline
\end{tabular}

The Universidad Icesi is mainly a teaching institution and because of this, the primary emphasis is on teaching development. In this sense, professors have expressed their concern in three aspects. First, class observations from peers and their impact on promotions. Second, the accompaniment for implementing new techniques and its impact on professor's evaluations. At Icesi there are no academic appointments, professors belong to each academic department. Finally, the support and incentives associated to the additional load that this might create, especially for part-time professors.

\section{CONCLUSIONS AND FUTURE DIRECTIONS FOR RESEARCH}

One way to advance in understanding and implementing of AL is through reflection. This implies that faculty not only carefully think about their practice but also take action on it. Faculty members reflect upon their courses every semester not only to adjust the syllabus and associated materials but also to reflect upon how they can improve teaching methods and teaching practice. Once this need is identified and recognized by the faculty member, the utility of the programs offered by the institution at various levels (i.e., departmental, school, and institutional) can become apparent and 
be incorporated into their development plan, which is reviewed with the department head. Department heads can therefore identify common gaps in order to either develop programs at the departmental level or to coordinate programs at the school or institutional level.

This research is the first attempt at gathering information about active learning practices within the School of Engineering and proposing a faculty development plan oriented toward improving faculty members' teaching practices and competencies. However, further work needs to be carried out to implement this faculty development plan and assess the real impact on the professors' daily practice, student learning and faculty member competencies. Class observation is paramount to contrast what professors plan to do, what they actually do, and what students perceive or learn. In this regard, $68 \%$ of the faculty members surveyed are willing to be observed in class and receive feedback from these observations in order to improve their practice. In addition, future research will also involve the development of a set of faculty competencies in order to align training efforts.

\section{REFERENCES}

[1] J. H. G. Zamora and A. B. Arias, El aprendizaje activo y la formación universitaria. Universidad Icesi, 2010.

[2] R. M. Felder, H. Celanese, and R. Brent, "Active Learning: an Introduction," ASQ High. Educ. Br., 2009.

[3] C. C. Bonwell and A. Eison, James, Active Learning: Creating Excitement in the Classroom. 1991 ASHE-ERIC Higher Education Reports. 1991.

[4] M. Prince, "Does active learning work? A review of the research," J. Eng. Educ., vol. 93, no. 3, pp. 223-232, 2004.

[5] M. J. Borrego, M. J. Prince, C. E. Nellis, P. Shekhar, C. Waters, and C. J. Finelli, "Student perceptions of instructional change in engineering courses: A pilot study," ASEE Annu. Conf. Expo., pp. 1-13, 2014.

[6] Z. Daouk, R. Bahous, and N. N. Bacha, "Perceptions on the effectiveness of active learning strategies," J. Appl. Res. High. Educ., vol. 8, no. 3, pp. 360-375, 2016.

[7] M. Prince and R. Felder, "Inductive Teaching and Learning Methods," Eng. Educ., vol. 95, no. 2, pp. 123-138, 2006.

[8] J. B. Higley and S. Scachitti, "Flipped Classroom or Active Learning : Integrating Alternative Teaching Meth- ods into Engineering Technology Curriculum," in 2018 ASEE Annual Confererence \& Exposition, 2018.

[9] R. M. Lima, P. H. Andersson, and E. Saalman, "Active Learning in Engineering Education: a (re)introduction,” Eur. J. Eng. Educ., vol. 42, no. 1, pp. 1-4, 2017.

[10] R. M. Felder, R. Brent, and M. J. Prince, "Engineering Instructional Development," in Cambridge Handbook of Engineering Education Research, A. Johri and B. M. Olds, Eds. Cambridge University Press, 2013, pp. 409-436.

[11] M. McLean, F. Cilliers, and J. Van Wyk, "Faculty development: Yesterday, today and tomorrow," Med. Teach., vol. 30, no. 6, pp. 555-584, 2008. 
[12] A. M. Knight, K. A. Cole, D. E. Kern, L. R. Barker, K. Kolodner, and S. M. Wright, "Long-term follow-up of a longitudinal faculty development program in teaching skills," J. Gen. Intern. Med., vol. 20, no. 8, pp. 721-725, Aug. 2005.

[13] Y. Steinert, "Learning together to teach together: Interprofessional education and faculty development," J. Interprof. Care, vol. 19, no. SUPPL. 1, pp. 60-75, 2005.

[14] Y. Steinert, "Faculty development in the new millennium: Key challenges and future directions," Med. Teach., vol. 22, no. 1, pp. 44-50, 2000.

[15] S. R. Cruess, J. D. Boudreau, A. Fuks, R. L. Cruess, and Y. Steinert, "Faculty Development as an Instrument of Change: A Case Study on Teaching Professionalism," Acad. Med., vol. 82, no. 11, pp. 1057-1064, 2009.

[16] M. Quirk, D. Lasser, F. Domino, A. Chuman, and S. Devaney-O’Neil, "Family medicine educators' perceptions of the future of faculty development," Family Medicine, vol. 34, no. 10. pp. 755-760, 2002.

[17] J. A. Van Amburgh, J. W. Devlin, J. L. Kirwin, and D. M. Qualters, "RESEARCH ARTICLES A Tool for Measuring Active Learning in the Classroom," Am. J. Pharm. Educ., vol. 71, no. 5, p. 85, 2007.

[18] R. M. Felder and R. Brent, "Effective Teaching," Chem. Eng. Educ., vol. 43, no. 1, pp. 15-16, 2009.

[19] H. G. Grimes-Casey, T. P. Seager, T. L. Theis, and S. E. Powers, "A game theory framework for cooperative management of refillable and disposable bottle lifecycles," J. Clean. Prod., vol. 15, no. 17, pp. 1618-1627, 2007.

[20] A. F. McKenna, B. Yalvac, and G. J. Light, "The role of collaborative reflection on shaping engineering faculty teaching approaches," J. Eng. Educ., vol. 98, no. 1, pp. 17-26, 2009.

[21] A. Burbano, G. V Ulloa, J. Jaramillo, and N. M. Villegas, "Engaging Faculty in Continuous Improvement : The Context of an ABET Ac- creditation Process," in 2018 ASEE Annual Confererence \& Exposition, 2018, no. Paper ID \#22629. 
Appendix A - Survey Section II

ICESI

FACULTAD DE

INGENIERIA

Aprendizaje Activo en Ingenierias

ESCUELA DE

CIENCIAS DE LA EDUCACIÓN

Sobre Aprendizaje Activo

* 8. Ha recibido alguna capacitación en docencia o en pedagogia? (ej: curso corto, diplomado, estudios formales)

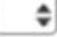

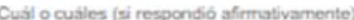

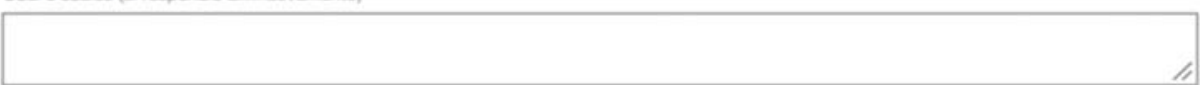

*9. En sus palabras, ¿Qué entiende por Aprendizaje Activo?

* 10. ¿Qué actividades de aprendizaje activo utiliza regularmente en sus clases? Mencione 3 de ellas.

Actividad 1:

Par qué la prefiere:

Peneficio percbido del uso en

clase.

Tempo de duracion

Tiempo estimado de

propareción

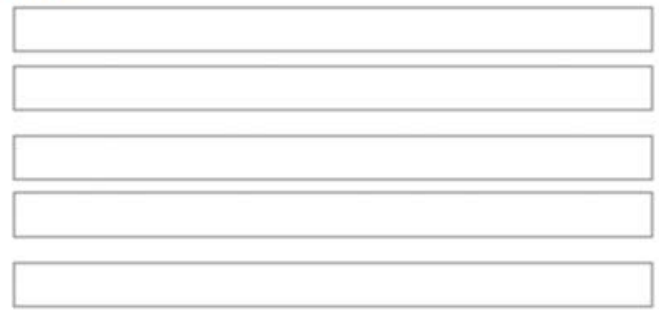

Explque corno realiza ta

conclusión o cierre de la.

actividad: 


\section{Appendix B - Proposed faculty development plan}

\begin{tabular}{|c|c|c|c|c|c|c|c|c|c|}
\hline \multirow[b]{2}{*}{ Carreer stage } & \multirow[b]{2}{*}{ Program ( examples ) } & \multicolumn{3}{|c|}{ Participation requirement } & \multicolumn{3}{|c|}{ Complexity Level } & \multicolumn{2}{|c|}{ Funding ( provider) } \\
\hline & & $\begin{array}{l}\text { Mandatory for } \\
\text { hiring }\end{array}$ & $\begin{array}{l}\text { Mandatory for } \\
\text { rank }\end{array}$ & \begin{tabular}{|l} 
Voluntary \\
*Incentives
\end{tabular} & Low & Medium & High & CREA & School of Eng. \\
\hline \multirow[t]{7}{*}{ Early Career } & Student Learning Styles & $\mathrm{X}$ & & & $\mathrm{X}$ & & & $\mathrm{X}$ & \\
\hline & Learning Objectives & $\mathrm{X}$ & & & $\mathrm{X}$ & & & $\mathrm{X}$ & \\
\hline & Evaluation Strategies & $\mathrm{X}$ & & & $\mathrm{X}$ & & & $\mathrm{X}$ & \\
\hline & Rubric construction** & & & $\mathrm{X}$ & $\mathrm{X}$ & & & & $\mathrm{X}$ \\
\hline & Instructional Design & $\mathrm{X}$ & & & $\mathrm{X}$ & & & $\mathrm{X}$ & \\
\hline & Communication & & & $\mathrm{X}$ & $\mathrm{X}$ & & & $\mathrm{X}$ & \\
\hline & Innovation in Higher Education & & & & & & & $\mathrm{X}$ & \\
\hline \multirow[t]{6}{*}{ Mid-Career } & Active Learning Techniques $* *$ & & & $\mathrm{X}$ & & $\mathrm{X}$ & & & $\mathrm{X}$ \\
\hline & Inverted Classroom & & & $\mathrm{X}$ & & $\mathrm{X}$ & & $\mathrm{X}$ & \\
\hline & Collaborative Reflection seminar ** & & & $\mathrm{X}$ & & $\mathrm{X}$ & & & $\mathrm{X}$ \\
\hline & Technology in the Classroom & & & $\mathrm{X}$ & & $\mathrm{X}$ & & $\mathrm{X}$ & \\
\hline & CLIL (Content and Language Integ. Learning) & & & $\mathrm{X}$ & & $\mathrm{X}$ & & $\mathrm{X}$ & \\
\hline & Diplomado en docencia universitaria & & $\mathrm{X}$ & & & $\mathrm{X}$ & & $\mathrm{X}$ & \\
\hline \multirow[t]{6}{*}{ Late Career } & Problem-based learning $(\mathrm{PBL})^{* *}$ & & & $\mathrm{X}$ & & & $\mathrm{X}$ & & $\mathrm{X}$ \\
\hline & Project-based learning $(\mathrm{PjBL}) * *$ & & & $\mathrm{X}$ & & & $\mathrm{X}$ & & $\mathrm{X}$ \\
\hline & Cooperative Learning** & & & $\mathrm{X}$ & & & $\mathrm{X}$ & & $\mathrm{X}$ \\
\hline & Cases / Casos cooperativos & & & $\mathrm{X}$ & & & $\mathrm{X}$ & $\mathrm{X}$ & \\
\hline & Classroom Assessment Techniques** & & & $\mathrm{X}$ & & & $\mathrm{X}$ & & $\mathrm{X}$ \\
\hline & Research on Engineering Education ** & & & $\mathrm{X}$ & & & $\mathrm{X}$ & & $\mathrm{X}$ \\
\hline
\end{tabular}

** Offered by the School of Engineering 2018

\begin{tabular}{|c|c|c|c|c|c|c|c|c|c|c|c|}
\hline \multirow[b]{2}{*}{ Carreer stage } & \multirow[b]{2}{*}{ Program ( examples) } & \multicolumn{4}{|c|}{ Program type } & \multicolumn{3}{|c|}{ Program focus } & \multicolumn{3}{|c|}{ Evaluation type } \\
\hline & & $\begin{array}{l}\text { Learning } \\
\text { communities }\end{array}$ & Workshop & Certificate & Diploma & $\begin{array}{l}\text { Theoretical } \\
\text { found. }\end{array}$ & $\begin{array}{l}\text { Tools and } \\
\text { Tech. }\end{array}$ & $\begin{array}{c}\text { Skills } \\
\text { Develop. }\end{array}$ & $\begin{array}{l}\text { Atendance } \\
\text { and satisfac. } \\
\text { Survey }\end{array}$ & $\begin{array}{l}\text { Impact on } \\
\text { teaching }\end{array}$ & $\begin{array}{l}\text { Impact on } \\
\text { students }\end{array}$ \\
\hline \multirow[t]{7}{*}{ Early Career } & Student Learning Styles & & $\mathrm{x}$ & & & $\mathrm{X}$ & & & $\mathrm{X}$ & $\mathrm{X}$ & \\
\hline & Learning Objectives & & $\mathrm{X}$ & & & & $\mathrm{X}$ & & $\mathrm{X}$ & $\mathrm{X}$ & \\
\hline & Evaluation Strategies & & $\mathrm{X}$ & & & & $\mathrm{X}$ & & $\mathrm{X}$ & & $\mathrm{X}$ \\
\hline & \begin{tabular}{|l|} 
Rubric construction** \\
\end{tabular} & & $\mathrm{X}$ & & & & $\mathrm{X}$ & & $\mathrm{X}$ & $\mathrm{X}$ & \\
\hline & Instructional Design & & $\mathrm{X}$ & & & & $\mathrm{X}$ & & $\mathrm{X}$ & $\mathrm{X}$ & \\
\hline & Communication & & $\mathrm{X}$ & & & & $\mathrm{X}$ & $\mathrm{X}$ & $\mathrm{X}$ & $\mathrm{X}$ & \\
\hline & Innovation in Higher Education & & $\mathrm{X}$ & & & $\mathrm{X}$ & & & $\mathrm{X}$ & $\mathrm{X}$ & \\
\hline \multirow[t]{6}{*}{ Mid-Career } & Active Learning Techniques ** & & & $\mathrm{X}$ & & & $\mathrm{X}$ & & $\mathrm{X}$ & $\mathrm{X}$ & \\
\hline & Inverted Classroom & & & $\mathrm{X}$ & & & $\mathrm{X}$ & & $\mathrm{X}$ & $\mathrm{X}$ & \\
\hline & \begin{tabular}{|l|} 
Collaborative Reflection seminar ** \\
\end{tabular} & $\mathrm{X}$ & & & & & & $\mathrm{X}$ & $\mathrm{X}$ & & $\mathrm{X}$ \\
\hline & Technology in the Classroom & & $\mathrm{X}$ & & & & $\mathrm{X}$ & & $\mathrm{X}$ & & $\mathrm{X}$ \\
\hline & \begin{tabular}{|l} 
CLIL (Content and Language Integ. Learning) \\
\end{tabular} & & & $\mathrm{X}$ & & $\mathrm{X}$ & & & $\mathrm{X}$ & $\mathrm{X}$ & \\
\hline & Diplomado en docencia universitaria & & & & $\mathrm{X}$ & $\mathrm{X}$ & $\mathrm{X}$ & $\mathrm{X}$ & $\mathrm{X}$ & $\mathrm{X}$ & \\
\hline \multirow[t]{6}{*}{ Late Career } & Problem-based learning (PBL)** & & & $\mathrm{X}$ & & & $\mathrm{X}$ & & $\mathrm{X}$ & $\mathrm{X}$ & \\
\hline & Project-based learning $(\mathrm{PjBL})^{* *}$ & & & $\mathrm{X}$ & & & $\mathrm{X}$ & & $\mathrm{X}$ & $\mathrm{X}$ & \\
\hline & \begin{tabular}{|l|} 
Cooperative Learning** \\
\end{tabular} & & & $\mathrm{X}$ & & & $\mathrm{X}$ & & $\mathrm{X}$ & $\mathrm{X}$ & \\
\hline & \begin{tabular}{|l|} 
Cases / Casos cooperativos \\
\end{tabular} & & $\mathrm{X}$ & & & & $\mathrm{X}$ & & $\mathrm{X}$ & $\mathrm{X}$ & \\
\hline & Classroom Assessment Techniques** & & & & & & $\mathrm{X}$ & & $\mathrm{X}$ & & $\mathrm{X}$ \\
\hline & Research on Engineering Education ** & $\mathrm{X}$ & & $\mathrm{X}$ & & & & $\mathrm{X}$ & $\mathrm{X}$ & & $\mathrm{X}$ \\
\hline
\end{tabular}

** Offered by the School of Engineering 2018 